\title{
LEVANTAMENTO DE ÁREAS DE RISCO A PARTIR DA DINÂMICA GEOAMBIENTAL DAS ENCOSTAS DA SERRA DO MAR NO PARANÁ
}

FABRÍZIA GIOPPO NUNES

\author{
DISSERTAÇÃO DE MESTRADO - Programa de Pós-Graduação em Geologia - UFPR \\ DATA DE DEFESA: 02 abr. 02
}

\begin{abstract}
O presente trabalho consiste na aplicação de um modelo matemático acoplado à utilização de técnicas de mapeamento temático em ambiente SIG, objetivando desenvolver uma metodologia voltada ao estudo dos fatores de segurança na estabilidade de encostas. Este modelo matemático, estruturado na distribuição das forcas atuantes em uma vertente infinita, leva em conta a influência da vegetação sobre as encostas, e os índices físicos e as propriedades mecânicas de cada unidade de solos. Os índices físicos e as propriedades mecânicas dos solos, bem como o papel da vegetação na estabilidade das encostas, permitiram a quantificação dos riscos de escorregamento para cada unidade de solo analisada. Como um primeiro resultado, apresenta-se a criação de um banco de dados digital, contendo informações preliminares das características do terreno, através da confecção de cartas temáticas tais como: topográfica, geológica, declividade e de uso e ocupação do solo dos anos de 1953, 1986 e 1999. Todas essas cartas fo-
\end{abstract}

ram transferidas para meio digital, permitindo as suas interpolações em ambiente sıG. Para os cálculos dos fatores de segurança das vertentes, foram considerados como atributos: a inclinação das encostas e as propriedades mecânicas dos solos, com a presença de água (solo saturado); a influência da cobertura vegetal (peso das árvores e sistema solo-raiz) e a força do vento atuando nas copas das árvores. As propriedades físicas e mecânicas dos solos (ângulo de atrito interno e coesão) foram determinadas pelo método de retroanálise desenvolvido por Lopes (1995). O método envolveu inicialmente a foto interpretação de cicatrizes de escorregamentos, para a elaboração de perfis topográficos, que determinaram os pares de altura/ângulo de taludes limites. Como resultado final, apresenta-se uma metodologia que possibilita o mapeamento dos diferentes graus de riscos ao escorregamento, a partir da interpolação em geoprocessamento das cartas temáticas com os dados obtidos pelas equações de fator de segurança. 